\title{
Organization for Security and Cooperation in Europe: Analysis of State, Prospects and Opportunities for Cooperation against the Illegal Migration and Terrorism
}

\author{
${ }^{1}$ Rustem Sh. Davletgildeev, ${ }^{2}$ Sergey A. Kostin \\ 1,2 Kazan Federal University \\ Email: roustem.davletguildeev@kpfu.ru,legaladress@list.ru
}

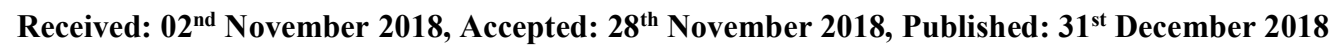

\begin{abstract}
This paper analyzes the activities of the Organization for Security and Cooperation in Europe (formerly the Conference on Security and Cooperation in Europe), the largest regional organization to date, which includes 57 sovereign states.

The Conference on Security and Cooperation in Europe (CSCE) was conceived as a major geopolitical project, the purpose of which was to relieve international tensions in security matters. Such an ambitious task led to the transformation of the Conference into the Organization for Security and Cooperation in Europe (OSCE) which has become an important element in the architecture of European security.

Rapid geopolitical changes in the conditions of uneven economic development of states objectively have influenced both the level of current threats and the formation of new threats in the field of security, among which international terrorism, illegal migration and human trafficking have become increasingly prominent.

As you know, the OSCE has three areas of development, otherwise referred to as "three baskets" (the "three baskets" system) and the crisis in the development of relations in one direction does not mean that relations in other areas should be frozen. On the contrary, the observed crisis in relations in the framework of one of the "baskets" may allow states to concentrate their efforts in the other two. Then the OSCE, with its potential, will once again become a link in cooperation between states related to the prevention of such threats as international terrorism, illegal migration and human trafficking.

The paper will analyze the OSCE activities regarding new possible institutional forms of cooperation related to the emergence of new threats to peace and security, in particular with regard to the possibility of cooperation in the field of illegal migration and combating terrorism, as well as possible ways to overcome the existing antagonistic contradictions in approaches to the development of European security systems.
\end{abstract}

\section{Keywords}

International Security; Illegal Migration; Organization for Security and Cooperation in Europe (OSCE); Regional Security; Cooperation; Terrorism; Human Trafficking

\section{Introduction}

The Conference on Security and Cooperation in Europe (CSCE) was conceived as a major geopolitical project, with the aim of alleviating the existing international tension in security matters. This ambitious task subsequently allowed the transformation of the Conference to the Organization for Security and Cooperation in Europe (OSCE or Organization), which became an important element in the architecture of European security.

The sphere of interests and competencies of the OSCE is considered to be based on the principle of the three "baskets", which is expressed in the form of the military-political, economic-ecological and human dimensions. In other words, these are issues related to the prevention of security threats due to possible military clashes of states, the prevention of economic and environmental disasters as factors affecting the level of stability and security, as well as threats caused by human rights violations and the proper functioning of democratic institutions.

The Organization for Security and Cooperation in Europe has good experience in countering the "standard" challenges and threats that are measured by one of the "baskets". Like everything else in this world, the Organization has experienced its boom and its recession. High hopes were placed first on the summit of leaders of countries in Astana (2010), which purpose was to address issues of quality improvement and reorganization of the OSCE. Later, hopes were placed on the Helsinki +40 project which was supposed to launch the OSCE reform process. As a result, the unfolding Ukrainian crisis exposed all the weaknesses of the Organization related to the lack of effective institutional tools to prevent regional conflicts in current realities.

Today, challenges that are "interdimensional" in nature, such as international terrorism, illegal migration and human trafficking, undermine the foundations of the national security of states. We believe that this circumstance can "push" countries to cooperate in the issues of developing a unified institutional framework that allows them to stop and prevent occurrence of the issues.

We will try to talk about all this in the study.

Materials and Methods

The materials used in the work were international treaties, resolutions and decisions of regional international organizations, official statements by the heads of state, as well as doctrinal studies related to ensuring international and 
regional security. The methodological basis of the research consists of specially legal, regulatory, teleological and systematic interpretations of international treaties, general scientific, as well as particular methods of cognition characteristic of legal sciences, including logical, formal legal, etc.

\section{Results and Discussion}

Between July 1973 and August 1975, three rounds of the Conference on Security and Cooperation in Europe took place in the cities of Geneva and Helsinki. The purpose of this meeting was the need to relieve the tensions that had arisen at that time in matters of security in the European region, in particular, with the strengthening of revanchist sentiments. The Conference meetings resulted in the signing of the Helsinki Final Act [1] (the Final Act or the Act) which confirmed "the territorial and political changes that occurred in Europe as a result of the defeat of Nazi Germany and post-war development" [2]. From an institutional point of view, the Act is interesting, firstly, because it has formulated ten principles of international law, which are now commonly considered to be also the basic principles of the jus cogens of the international law. Secondly, the Act defines the competencies and directions of development and cooperation through the "three baskets" system: military-political aspects; cooperation in the economic and humanitarian fields; and, in the field of human rights "[3]. Different points of view were expressed in the Soviet and further Russian doctrines of international law on the validity of the Final Act [4]. The reason for this was the Act "On the Procedure for Ratification and Denunciation of International Treaties" [5], in accordance with Article 2 of which "ratification of peace treaties concluded by the USSR, treaties on mutual defense against aggression, non- aggression treaties are subject to ratification. Equally, ratifications are subject to international treaties, at the conclusion of which the parties have agreed on their subsequent ratification". As is known, the Final Act did not require ratification and entered into force on the day of its signing. As some authors note: "The nature of these norms is very ambiguous... Rather, they represent the provisions of an organizational, political, moral and legal nature" [6], for this reason the concept of "agreement" [7] has become firmly established. As a result of the obvious desire of states to jointly resolve issues in the matter of ensuring European security, the format of the Conference was transformed into an Organization that firmly occupied its place in the European security architecture. Professor G.I. Kurdyukov highlights the "three main periods" associated with this [8]. In the so-called "first period", countries actively used the format of the Conference for interaction in a bipolar world: this was the "cold war". As a result, the Conference turned into a universal mechanism of pan-European cooperation. The collapse of the Soviet Union had the effect of a bomb exploded in the geopolitical picture of the world and led to a fundamental change in the situation, primarily in the European region. The so-called "second period" was entirely connected with the events of the 90 s of the 20th century, in particular with the need to coordinate the activities of states in the development of the institutional framework of the European security system. The "Challenge of the Time for Change" document (Helsinki, 1992) launched the process of transforming the Meeting from a political forum into a regional international organization with a corresponding structure [9] and institutions [10].

This allowed the Organization to participate in solving regional and ethnic conflicts, including in Bosnia and Herzegovina, Kosovo, Macedonia, Moldova, Nagorno-Karabakh, Kyrgyzstan, Tajikistan, Croatia, and Chechnya [11]. The turn of the XX-XXI centuries and up to the present is the "third period", and it is characterized by crisis phenomena in the "military-political" dimension of the OSCE activities. During this period, "OSCE participating States have failed to reach consensus on protracted conflicts and agree on a results-oriented action plan" with increasing frequency [12]. Within the framework of the OSCE Council of Foreign Ministers (COM) meetings, Minister of Foreign Affairs of Russia S.V. Lavrov repeatedly gave critical assessments of the OSCE, noting that "the situation in the OSCE's militarypolitical dimension is characterized by the degradation of the regime" [13], "the lack of necessary reforms - at least from the Russian point of view - will call into question the very need for the existence of this Organization" [14]. The cardinal renewal of the Organization was proposed to be carried out within the framework of the Irish project "Helsinki +40 ". When commenting the initiative, the representative of the Russian Foreign Ministry, Alexander Lukashevich said that "among the priorities, we consider the development of a legally binding charter of the OSCE" [15], because "without this kind of document, the OSCE cannot be regarded as a fully-fledged international organization". [16] Professor G.I. Kurdyukov, in turn, proposes "to start reforming the Organization with its main bodies" [17].

In the opinion of some authors, the Georgian-Ossetian-Abkhaz Conflict (2008) and the Ukrainian Conflict (2014) “temporarily attracted increased attention to the OSCE's activities; this also exposed the Organization's weaknesses, such as the lack of effective tools, limited mandate and too long decision-making procedures. The conflict prevention mechanisms at the disposal of the OSCE did not allow preventing and pacifying the conflict at the very beginning". [18]In 2014, an attempt was made using the OSCE format to resolve the Ukrainian crisis, in particular, a Memorandum on the implementation of the Protocol's provisions was signed following consultations of the tripartite contact group on steps aimed at implementing the Peace Plan by the President of Ukraine Petro Poroshenko and initiatives by the President of Russia Vladimir Putin [19].

However, it did not lead to a practical resolution of the conflict. Also in 2014, at the initiative of Switzerland and under the auspices of the OSCE, a "Group of eminent persons on European security as a common project" (Group of Wise Men) was convened with the aim of "finding ways to restore confidence in strengthening peace and security in the OSCE region" which revealed "Multiple and formidable disagreements". The report published in 2015 presented "Looking from the West", "Looking from Moscow" and "Viewpoint of Intermediate States: A View from Tbilisi" on the events of the $90 \mathrm{~s}$ and $00 \mathrm{~s}$, as well as on the current situation, including on European issues security. The Organization for Security and Cooperation in Europe has, perhaps, the greatest involvement of states compared to any 
other regional international organization and non-using of this advantage seems to be an irrational choice. In the current geopolitical situation, the OSCE format can be effectively used in terms of coordinating counter-terrorism activities, countering trafficking in persons and developing effective solutions to countering illegal migration. Moreover, such problems, as a rule, extend beyond the territory of one and even a group of states. In such a situation, crime prevention actions need to be coordinated in a wider international format. In particular, the struggle and counteraction against acts of terrorism in the European space is the responsibility of a number of regional organizations such as the OSCE represented by the Anti-Terrorist Division of the Department of transnational threats included in the OSCE Secretariat [20], the Council of Europe represented by the Council of Europe Counter-Terrorism Committee (CDCT) (previously CODEXTER) [21].

Eurojust and Europol are responsible for coordinating the investigation of crimes involving two or more states within the European Union. The list of competencies of Eurojust is provided for by article 4 of the Council Decision ( 2002/187 / JHA) [22], Europol, and also by article 4 of the Council Decision [23] which include crimes of a terrorist nature. According to D.Yu. Bazarkina, "the problem of intersection between functions of individual structures remains, what often leads to contradictions in the EU antiterrorist policy" in the fight against terrorism on the territory of the European space [24]. According to some authors, "...with the end of the cold war, the concept of security has undergone a transformation. States and, in particular, their external security agencies, which have traditionally worked against an external enemy, have identified new threats, such as terrorism and international crime, which "merge" in the image of a migrant" [25], as well as the increased due to above "the demand to develop a security policy that is able to identify and manage security vulnerabilities" [26].Many people recognize that "at the beginning of the 21st century, migration is the most important global problem," noting that "migration control has become the last bastion of sovereignty, and sovereignty itself is also transforming... For this reason, the values of law and order which we can now observe in the international sphere are themselves a consequence of the relationship between migration law and sovereignty". [27] Indeed, the globalization of the modern world has both favorable and unfavorable consequences, among which the problems of illegal migration and human trafficking are becoming more and more prominent. First of all, they point out on "poverty and inaccessibility of effective employment, allowing life worth living" as the reasons for illegal migration. [28] A number of authors note that ", developed countries and the legal and economic security of their citizens highlighted in the media are a real temptation for residents of poor countries, and illegal migration is increasingly being chosen as a way to get into such a country" [29]. At the same time, it is said that "illegal migration, in itself, is not human trafficking. However, illegal migrants are at risk and often fall into slavery or find themselves in a similar position, being unable to appeal to the authorities of the country where they stay illegally" [30]. It should be noted that "illegal migration and forced migration are factors that work against regional integration," while "within the framework of certain regional integration entities, a special legal regime is created to ensure the free movement and employment of citizens of the states participating in such an education" [31].Within the framework of the OSCE, the Office for Democratic Institutions and Human Rights (ODIHR) deals with migration issues. Based on OSCE commitments, ODIHR helps participating States to assess, design and implement gender-sensitive migration policies and legislation, protect the basic rights of migrants and promote the integration of migrants into the societies in which they live. In these areas, the ODIHR identifies and facilitates the sharing of best practices, comparing them with the needs identified in the participating States [32]. In addition, an independent activity of the OSCE is the fight against trafficking in persons. In 2003, the Organization established the Office and established the post of Special Representative and Coordinator on Combating Trafficking in Persons to assist participating States in developing and implementing effective policies to combat trafficking in persons. In the same year, the OSCE Permanent Council adopted decision No. 557 which approved the OSCE Action Plan on Combating Trafficking in Persons [33]. This has defined the OSCE priorities in the area: prosecution, including investigation and enforcement, prevention of trafficking in persons, protection and assistance to victims of trafficking in persons. In 2013, another direction - partnership, - was highlighted in the Action Plan, focusing on the need for closer interaction with international organizations and other partners.

\section{Summary}

The Organization for Security and Cooperation in Europe is seriously exposed to the geopolitical situation, and the findings of the "Group of Wise Men" report confirmed the antagonistic contradictions in the approaches to reforming the European model of ensuring collective security. In such a situation, as Professor L.S. Voronkov said: "The hopes for turning the OSCE into a basic or even more or less important institution in the system of all-European security and cooperation are not quite justified in this situation". [34] However, the OSCE continues to be a necessary format for interaction, when and, if states have such a need. As one of the most famous international lawyers, F.F. Martens once said in relation to the International Court of Arbitration: "In all international disputes, in which the political element comes first, the arbitration is impossible. It is applicable only to such, for the most part, non-essential disagreements of the states in which the interests of a legal nature are mainly involved, when it is necessary to clarify the rights belonging to the parties. Out of respect for the International Court of Arbitration, we should not expand its competence and set it tasks that cannot be resolved from the point of view of the law" [35]. So in the case of the OSCE, the adoption of a consolidated constituent act is a difficult task, firstly, by itself, since in this case the act will have to absorb a huge array of information and documents adopted by the participants since 1975. Secondly, in terms of antagonistic contradictions between visions of European security architecture, it seems difficult to achieve a consensual solution within the 
framework of the OSCE. In their interview with the Editor-in-Chief of the Security Index of the Director of DOS MFA of the Russian Federation, Russia's Permanent Representative to the Organization for Security and Cooperation in Europe (2011-2015) Andrei Kälin and the head of the working group on the preparation of the chairmanship of Germany in the OSCE in 2016 Antje Lönderts, speaking of the solution of such common security problems as international terrorism, drug trafficking or migration, noted that "extensive opportunities open up for closer cooperation as a result of improved regional ties, which will contribute to the development of investment and trade, including beyond existing economic integration structures. Progress in these areas can also help restore confidence, which is the only sound basis for sustainable security. "[36] Currently, there are no independent institutions that would deal with the problems of preventing acts of terrorism, illegal migration and human trafficking within the OSCE. Separate attempts, like the OSCE Action Plan to Combat Trafficking in Persons [37], assistance in the elaboration of the EU Council Decision dated July 19, 2002 "On Combating Trafficking in Persons" and Decisions 2004/68 / LDP dated December 22, 2003 "On the fight against the sexual exploitation of children and child pornography," as well as a number of others, of course, are aimed at harmonizing national legislations and developing unified approaches of states to these problems. However, clarifying the OSCE's internal organization of work and delimiting its competencies between the existing structures and institutions in the area of "inter-dimensional" aspects, as a direction for developing an institutional framework, would enable states to develop closer cooperation in such key areas, using the resources of the Organization, and taking into account that these problems are less susceptible to political conjuncture and can be a link within the member countries of the Organization.

\section{Conclusion}

The Organization for Security and Cooperation in Europe was initially created as a forum for dialogue, coordination of foreign policies of states, developing constructive solutions for cooperation, and finding new areas for interaction. Perhaps now it is the fact that OSCE resolutions continue to be of a recommendatory nature, this allows the Organization to preserve its existence in the midst of the growing confrontation of the member states and to cooperate in those areas where there are common points of contact and mutual interests.

Having evolved, the Organization has retained its key features, such as the equal status of member states and cultural dialogue, which allow for open discussions related to the prevention of new threats in the field of security and increasing confidence in each other, when states are interested in this.

\section{Acknowledgments}

The work is performed according to the Russian Government Program of Competitive Growth of Kazan Federal University.

\section{References}

[1]. The text of the 1975 Final Act of the CSCE // From Helsinki to Budapest: The history of the CSCE / OSCE in the documents of 1973-1994. In three volumes. V.1. - M. : Science, 1996. Pp. 47-87.

[2]. Mazov V.A. Principles of Helsinki and international law. M. : Science, 1979. P. 215.

[3]. See the Subsection: Dronov V. From CSCE to OSCE: Historical Retrospective // Aspect of Statehood and Institutionalism in Contemporary Euro. - GB. Aldershot, 1997. P. 106.

[4]. See for example: Mullerson R.A. Ch.H. "International law, foreign policy and diplomacy "// The course of international law in seven volumes. V. 1. Pp. 304-305.

[5]. Law "On the Procedure for Ratification and Denunciation of International Treaties by the Union of Soviet Socialist Republics" dated August 20, 1938

[6]. International Law: Textbook for Bachelors / Responsible Editor R.M. Valeev, G.I. Kurdyukov. - M. : Statute, 2017. - 496 p. (Textbook of Kazan University.). Pp. 298.

[7]. See for example: Shatrov V.P. Ch.VII "Helsinki unification process" // The course of international law in seven volumes. V.7. P. 157; Hydrim A.V. The legal nature of the CSCE Final Act: Author's abstract of the dissertation of the candidate of legal sciences. M., 1980.

[8]. Kurdyukov G.I. The role of the Organization for Security and Cooperation in Europe (CSCE / OSCE) in the development of the world political process at the turn of the twenty-first century. Kazan: CJSC "Novoye Izdaniye", 2008.Pp. 7-15.

[9]. See the Subsection: CSCE, Budapest Summit Declaration, Towards a Genuine Partnership in a New Area. Budapest. December 6, 1994. SIPRI Yearbook. 1995

[10]. See the Subsection: Bekyashev K.A. Dispute resolution within the OSCE. International public law: textbook / L.P. Anufriev, K.A. Bekyashev, E.G. Moiseev, V.V. Ustinov (and others); executive editor K.A. Bekyashev. 5th edition, revised and enlarged. - M.: Prospect, 2011. Pp. 250-251.

[11]. See, for example, Implementation of the Moscow OSCE Mechanism. OSCE official website. // URL: "http://www.osce.org/ru/odihr/84451" (access date - August 02, 2018).

[12]. Interpretative Statement by the Canadian delegation in accordance with paragraph 6 of Section IV.1 (A) of the Rules on the OSCE Procedure. December 2010. OSCE official website. // URL: http://www.osce.org/ru/cio/74990?download=true (access date - August 02, 2018). 
[13]. Speech by the Minister of Foreign Affairs of the Russian Federation S.V. Lavrov at the plenary meeting of the OSCE Ministerial Council, Dublin, December 6, 2012. 2298-06-12-20 12.Ministry of Foreign Affairs of the Russian Federation, Department of Information and Press, December 6, 2012.

[14]. See ibid.

[15]. "Rossijskaya gazeta" dated November 22, 2012. The Russian Federation will raise the issue of abolishing visas at a meeting of OSCE foreign ministers. URL: http://www.rg.ru/2012/11/22/vizy-anons.html (access date - August 02, 2018).

[16]. Interpretative statement by the Russian delegation at the 14th meeting of the OSCE Foreign Affairs Council held dated December 4-5, 2006 in Brussels. MC.DEC / 16/06 / Corr.1 Official OSCE website. URL: https://www.osce.org/ru/mc/25070?download=true (access date - August 2, 2018).

[17]. Kurdyukov G.I. The role of the Organization for Security and Cooperation in Europe (CSCE / OSCE) in the development of the world political process at the turn of the twenty-first century. Kazan: CJSC "Novoye Izdaniye", 2008.Pp. 18-30.

[18]. Spencer Oliver and Maria Chepurina. Time for a new OSCE strategy? Security Community (OSCE Magazine), Issue No. 1/2015. P.21

[19]. The Memorandum on the implementation of the Protocol's provisions following the consultations of the Tripartite Contact Group on joint steps aimed at implementing the Peace Plan of the President of Ukraine P. Poroshenko and initiatives of the President of Russia V. Putin. OSCE official website. // URL: http://www.osce.org/ru/home/123807?download=true (access date - May 26, 2018).

[20]. OSCE Secretariat. // URL: https://www.osce.org/ru/secretariat/terrorism (access date - June 12, 2018).

[21]. Council of Europe Convention on the Prevention of Terrorism, Warsaw 2005. Council of Europe official website. //URL:https://rm.coe.int/CoERMPublicCommonSearchServices/DisplayDCTMContent?documentId=09000016808c3f5 5 (access date - July 12, 2018).

[22]. Council Decision of 28 February 2002 setting up Eurojust with a view to reinforcing the fight against serious crime (2002/187/JHA). Official Journal of the European Communities. Eurojust official website. // URL: http:/www.eurojust.europa.eu/doclibrary/Eurojustframework/ejdecision/Eurojust\%20Decision\%20\%28Council\%20De cision\%202002-187-JHA\%29/Eurojust-Council-Decision-2002-187-JHA-EN.pdf (access date - July 12, 2018).

[23]. Regulation (EU) 2016/794 of the European Parliament and of the Council of 11 May 2016 on the European Union Agency for Law Enforcement Cooperation (Europol) and replacing and repealing Council Decisions 2009/371/JHA, 2009/934/JHA, 2009/935/JHA, 2009/936/JHA and 2009/968/JHA. Official Journal of the European Communities // URL: https://www.europol.europa.eu/publications-documents/regulation-eu-2016/794-of-european-parliament-and-ofcouncil-of-11-may-2016 (access date - July 12, 2018).

[24]. D.Yu. Bazarkin. Coordination of counter-terrorism activities in the EU: a brief overview of the main organizations. Bulletin of MGOU. Series "History and political science." № 2/2012. Pp. 83-84.

[25]. Idil Atak and François Crépeau. National security, terrorism and the securitization of migration. Research handbook on international law and migration Edited by Vincent Chetail and Céline Bauloz (2014) P. 94. // URL: https://www.e-elgar.com/shop/eep/preview/book/isbn/9780857930057/ (дата обращения - 25 июля 2018).

[26]. ibid. P. 95.

[27]. Catherine Dauvergne. Irregular migration, state sovereignty and the rule of law. ISBN: 978-0-85793-004-0 (cased). P. 92.

[28]. See: "Trafficking in Persons in the Russian Federation. Review and analysis of the current situation on the problem. Study by E.V. Tyurukanova together with the Institute of Urban Economics Foundation for a working group of UN agencies and the International Organization for Migration (IOM) on human trafficking. M. (2006). S. 31.

[29]. Silva Petrosyan, Geghine Khachatryan. "Trafficking in Persons (Trafficking) A Handbook for Teachers and Students.” International Organization for Migration (IOM Mission in Armenia), 2013. P. 33.

[30]. Ibid. P. 34.

[31]. International Law: Textbook for Bachelors / Executive editors R.M. Valeev, and G.I. Kurdyukov. - M. : Statute, 2017. - 496 p. (Textbook of Kazan University.). Pp. 223.

[32] Migration. OSCE official website. URL: https://www.osce.org/odihr/migration (access date - August 27, 2018).

[33] Decision No. 557 "On the OSCE Action Plan to Combat Trafficking in Persons dated July 24, 2003” // PC.DEC / 557.URL: https://www.osce.org/ru/pc/42712?download=true (access date - August 27, 2018).

[34]. Voronkov L.S. "OSCE and European security. What's next?" Modern Europe, 2018, №1, p. 77.

[35]. Martens F.F. Modern international law of civilized nations. V. II. St. Petersburg. 1883. Pp. 451-452.

[36]. See: "The OSCE remains the only platform where all interested parties can engage in a dialogue on the present and the future of the common security system." Security Index No. 3 (114), Volume 121 (2015). P.22. URL: http://pircenter.org/media/content/files/13/14482851180.pdf (access date - 04 August 2018).

[37]. Solution No. 557 "On the OSCE Action Plan to Combat Trafficking in Persons". OSCE official website. // URL: https://www.osce.org/ru/pc/42712?download=true ; Solution No.557 / Rev.1. "On the OSCE Action Plan to Combat Trafficking in Persons". OSCE official website. // URL: https:/www.osce.org/ru/pc/15948?download=true (access date - July 24, 2018). 